\title{
Enhanced fed-batch production, partial purification, characterization of jenseniin $P$, and discovery of a new bacteriocin-like substance produced by Propionibacterium jensenii B1264
}

\author{
Gaoyan Wang • John G. Abercrombie • Guohui Huang • \\ Tzuen-Rong Jeremy Tzeng
}

Received: 6 November 2013 / Revised: 28 February 2014 / Accepted: 10 March 2014 / Published online: 28 March 2014

(C) Springer-Verlag Berlin Heidelberg 2014

\begin{abstract}
Propionibacterium jensenii B1264 was discovered to inhibit various Propionibacterium, Lactobacilli, and Lactococcus strains based on a deferred agar spoton-lawn detection method in previous research, in which Lactobacillus delbrueckii ssp. lactis ATCC 4797 was the most susceptible one. The antimicrobial substance(s) was named jenseniin P and L. delbrueckii ssp. lactis ATCC 4797 was thereafter used as the indicator strain in subsequent research. In current study, production of jenseniin $\mathrm{P}$ was significantly enhanced via an improved fed-batch fermentation method and was partially purified using reverse phase silica gel (C18). This partially purified jenseniin $\mathrm{P}$ was inactivated by trypsin, pronase, and proteinase $\mathrm{K}$. The molecular weight of jenseniin $\mathrm{P}$ was determined to be between 4.5 and $5 \mathrm{kDa}$. Jenseniin $\mathrm{P}$ was characterized as being $\mathrm{pH}$ stable with partial inactivation at $100{ }^{\circ} \mathrm{C}$. Jenseniin $\mathrm{P}$ was determined to be bactericidal, causing $2.38 \mathrm{log}$ reduction within $60 \mathrm{~min}$ at room temperature. A new bacteriocin-like inhibitory substance (BLIS) produced by P. jensenii B1264 was discovered in this study. The new BLIS inhibited the growth of Propionibacterium acnes ATCC 6919 but not the previously used indicator strain L. lactis ATCC 4797. The new discovered BLIS was recovered from the $30 \%$ acetonitrile
\end{abstract}

Gaoyan Wang and John G. Abercrombie have contributed equally to this work.

G. Wang $(\bowtie) \cdot$ J. G. Abercrombie · G. Huang · T.-R. J. Tzeng

Department of Biological Sciences, Clemson University,

Clemson, SC 29631, USA

e-mail: gw236@cornell.edu

Present Address:

G. Wang

Department of Food Science, Cornell University, Geneva,

NY 14456, USA elution fraction of $\mathrm{C} 18$ resin silica column purification process. This new BLIS might present new potential application in the pharmaceutical industry for acne treatment.

Keywords Bacteriocin - Fed-batch fermentation · Purification $\cdot$ Stability $\cdot$ Bactericidal $\cdot$ Anti-acne

\section{Introduction}

Bacteriocins are ribosomally encoded peptides or proteins that usually exhibit antimicrobial activity against species genetically closely related to the producer strains [1]. Various bacteriocins produced by Gram-positive bacteria, especially lactic acid bacteria, have been purified and characterized [2], and most of the characterized bacteriocins thus far show relatively narrow spectrum of inhibition [3]. The most intensively studied bacteriocins are produced by lactic acid bacteria since they are categorized as "Generally Recognized As Safe" (GRAS) and have the most immediate potential in being applied in the food industry.

Based on their habitats, the genus Propionibacterium is divided into classical and cutaneous species [4]. Classical propionibacteria, typically including $P$. freudenreichii, Propionibacterium jensenii, $P$. thoenii, $P$. acidipropionici, and $P$. cyclohexanicum [5], are known as "food grade" microorganisms since they have been widely used in dairy products and olive fermentations for a longtime [6]. As starter cultures, their presence contributes to the characteristic flavors and desirable textures for fermented foods. Classical propionibacteria are responsible for the typical "eyes" in Swiss cheese. They are also used in industry in the production of vitamin $B_{12}$, propionic acid, acetic acid, and bacteriocins [5]. Several bacteriocins produced by classical propionibacteria have been described including jenseniin $G$ 
[7], jenseniin P [8], a precursor protein of an antimicrobial peptide (PAMP) [2], propionicin PLG1 [9], propionicin T1 [3], propionicin SM1 and SM2 [10], and propionicin F [1]. Cutaneous propionibacteria are among the most common anaerobic microorganisms proliferating on human skin. This group typically includes Propionibacterium acnes, $P$. avidum, $P$. granulosum, and $P$. lymphophilum [11], in which $P$. acnes is the major pathogen that causes inflammation in acne vulgaris development [12]. Very few bacteriocins or bacteriocin-like inhibitory substances (BLIS) have been reported to inhibit $P$. acnes to date $[13,14]$. However, these types of BLIS(s) attract great interest in the pharmaceutical industry for acne treatment due to the emergence of antibiotic resistant microorganisms $[14,15]$.

In 1993, Prince discovered that $P$. jensenii B1264 inhibited the growth of several species of dairy Propionibacterium, Lactobacilli, and Lactococcus by the deferred agar spot-on-lawn detection method. The inhibitory agent(s) was defined to be a bacteriocin and was named jenseniin P. However, based on this previous study, it was not clear whether one or more bacteriocins were responsible for the antimicrobial activity against the above reported species because original assays were conducted using filtered and concentrated spent culture medium. Lactobacillus delbrueckii ssp. lactis ATCC 4797 was the most sensitive strain of all strains tested and has been used as the indicator strain to assess jenseniin $\mathrm{P}$ activity afterward [16]. In subsequent studies, Ratnam partially purified jenseniin $P$ by anion exchange chromatography and the crude jenseniin $\mathrm{P}$ was discovered to be also antagonistic against many clinical isolates of $P$. acnes [17]. In 2000, Wallin produced jenseniin $\mathrm{P}$ in batch and fed-batch cultures recording the maximum activity in the fed-batch system at $400 \mathrm{AU} / \mathrm{ml}$ [18].

The objective of this research is to develop more efficient growth conditions to produce a sufficient amount of jenseniin $\mathrm{P}$ and a better purification system to purify the bacteriocin for subsequent stability and characterization studies. In addition, purification of the bacteriocin will help to determine whether more than one bacteriocin(s) exists in the partially purified supernatant.

\section{Materials and methods}

Bacterial strains, chemicals, and growth conditions

Jenseniin P producer strain P. jensenii B1264 and L. delbrueckii ssp. lactis ATCC 4797 were obtained from Dr. Susan Barefoot, Clemson University, South Carolina. P. acnes ATCC 6919 was purchased from American Type Culture Collection (ATCC, Manassas, VA). L. delbrueckii ssp. lactis ATCC 4797 was cultivated at $35{ }^{\circ} \mathrm{C}$ with $5 \%$ $\mathrm{CO}_{2}$ in lactobacilli MRS broth or MRS agar. P. acnes and
P. jensenii were incubated at 37 and $32{ }^{\circ} \mathrm{C}$, respectively, in sodium lactate broth (NLB) consisting of $1 \%$ tryptic soy broth without dextrose, $1 \%$ yeast extract, and $1 \%$ sodium lactate (syrup, $60 \% \mathrm{w} / \mathrm{w}$ ). Sodium lactate agar (NLA) plates and soft NLA overlay were prepared by adding 1.5 or $0.75 \%$ agar to NLB, respectively. The anaerobic growth environment for propionibacterial cultures grown on NLA plates, or in small volume, NLB was generated by the addition of an anaerobic gas mixture $\left(\mathrm{H} 9.5 \%, \mathrm{CO}_{2} 10.5 \%\right.$, N $80 \%$ ) using the Anoxoma AN2CTS system (Spiral BioTech, Holland). Larger volume of $P$. jensenii cultures were grown in a 21 bioreactor (BioFlo 110 Fermentor/Bioreactor, New Brunswick Scientific, Connecticut USA) under conditions of reduced oxygen by sparging with nitrogen gas during incubation.

\section{Fed-batch fermentation}

Fed-batch fermentation was carried out in a 21 bioreactor with slow agitation (100 rpm). P. jensenii B1264 was refreshed from frozen culture $\left(-80{ }^{\circ} \mathrm{C}\right)$, subcultured two times on NLA plates, and subsequently transferred to NLB. A $1 \%$ inoculum of a 4-day broth culture of $P$. jensenii B1264 was inoculated to the 21 NLB in the bioreactor and incubated at $32{ }^{\circ} \mathrm{C}$ for 18 days with constant slow agitation. Sodium lactate (syrup, $60 \%$, w/w) was added to the fermenter twice daily to provide a $0.3 \%$ feeding by volume. Samples $(5 \mathrm{ml})$ of cultures were taken daily for bacteriocin activity assay against $L$. delbrueckii ssp. lactis ATCC 4797 , turbidity $\left(\mathrm{OD}_{600}\right)$, viable cells count $(\mathrm{CFU} / \mathrm{ml})$, and $\mathrm{pH}$ measurements. Viable cell counts $(\mathrm{CFU} / \mathrm{ml})$ were determined by making appropriate dilutions of daily culture samples to the surface of NLA plates in triplicate and incubating the plates anaerobically. In preliminary batch of fermentation, the culture was fermented in the same condition for 33 days to determine a time point of maximum jenseniin $P$ production. In the experimental batch of fermentation, cultures were harvested at day 18 for subsequent purification.

Partial purification of jenseniin $P$

Supernatant ( $2 \mathrm{~L}$ ) was collected by centrifugation (15 min, $4{ }^{\circ} \mathrm{C}, 10,000 \mathrm{~g}$ ) and filtered (polyethersulfone membrane $0.45 \mu \mathrm{m})$ and was dialyzed (3500MWCO membrane) twice against 121 of $50 \mathrm{mM}$ sodium phosphate buffer overnight. The supernatant was concentrated by freeze drying using Virtis DBT Benchtop 7.0 1 Freeze Dryer (SP Industries; Warminster PA, USA) and was resuspended in $50 \mathrm{ml}$ sodium phosphate buffer $(50 \mathrm{mM})$. Concentrated sample was partially purified by reversed phase chromatography. In brief, $0.5 \mathrm{~g} \mathrm{C} 18$ reverse phase silica gel (Cat \# 360130500, Acros Organics) was placed in a plastic disposable column and was successively eluted by $5 \mathrm{ml}$ of $5 \%$ acetonitrile 
solution plus $0.1 \%$ trifluoroacetic acid (TFA), $99.9 \%$ acetonitrile plus $0.1 \%$ TFA, and $5 \%$ acetonitrile solution plus $0.1 \%$ TFA to equilibrate the column. Second, $1 \mathrm{ml}$ dialyzed sample was loaded onto the resin and incubated by shaking on an ice bed for $1 \mathrm{~h}$. Third, the resin was successively eluted with $5 \mathrm{ml}$ of $50 \mathrm{mM}$ sodium phosphate buffer ( $\mathrm{pH}$ 6.4), 10, 20, 30, 40, 50, and $100 \%$ acetonitrile solution plus $0.1 \%$ TFA. Elutes from each fraction were separately collected and freeze-dried to completion and resuspended in one milliliter buffer. Bacteriocin activity of each fraction was measured by the microtiter plate method, and the active fraction was used in subsequent characterization studies.

\section{SDS-PAGE and overlay assay}

The partially purified jenseniin $\mathrm{P}(5,120 \mathrm{AU} / \mathrm{ml})$ was loaded onto Tris-Tricine SDS-PAGE (18\% acrylamide) in duplicate. Low-Range Rainbow Molecular Weight Marker (Amersham Biosciences, RPN 755) was loaded in a separate lane. The gel was run at a constant voltage of $100 \mathrm{~V}$ for $45 \mathrm{~min}$. Half of the gel was stained by silver staining, while other half was washed in $200 \mathrm{ml}$ of $2.5 \%$ Triton X-100 for $1 \mathrm{~h}$, followed by $200 \mathrm{ml}$ of sterile distilled water for $4 \mathrm{~h}$ with gentle shaking [10]. The washed gel was placed on a MRS plate and overlaid with $8 \mathrm{ml} 0.75 \%$ soft MRS agar seeded with $50 \mu 1 \mathrm{~L}$. delbrueckii ssp. lactis ATCC 4797 and incubated as previously described. Bands exhibited on the stained gel and the clear inhibitory zones exhibited on the overlay were compared.

\section{Bactericidal effect}

An overnight culture of $L$. delbrueckii ssp. lactis ATCC 4797 was centrifuged and resuspended in $50 \mathrm{mM}$ phosphate buffer (PBS) with $\mathrm{OD}_{600} 1.0\left(\sim 10^{7} \mathrm{CFU} / \mathrm{ml}\right)$. The washed cell suspension $(500 \mu \mathrm{l})$ was mixed with $500 \mu \mathrm{l}$ of partially purified jenseniin $\mathrm{P}(5,120 \mathrm{AU} / \mathrm{ml})$ in PBS and held at $37{ }^{\circ} \mathrm{C}$ for $60 \mathrm{~min}$ with gentle shaking. Aliquots $(50 \mu \mathrm{l})$ taken in $10 \mathrm{~min}$ intervals were plated to determine viable cell counts $(\mathrm{CFU} / \mathrm{ml})$ by making appropriate dilutions of daily cultures to the surface of MRS agar plates and incubating at $37{ }^{\circ} \mathrm{C}$ overnight. Three experiments in triplicates were performed.

\section{Enzyme treatment}

Aqueous solution $(25 \mu \mathrm{l}$ each) of trypsin, proteinase $\mathrm{K}$, pronase, lysozyme, and catalase $(10 \mathrm{mg} / \mathrm{ml})$ were loaded onto sterilized disks ( $7 \mathrm{~mm}$ in diameter) on top of MRS agar plates. At a $1 \mathrm{~mm}$ distance, $25 \mu \mathrm{l}$ of partially purified jenseniin P (5120 AU/ml) was loaded onto identical disks. The close distance allowed the enzymes to partially diffuse to the jenseniin $\mathrm{P}$ disk. After $1 \mathrm{~h}$ of incubation at $37{ }^{\circ} \mathrm{C}$, the plate was overlaid with $L$. delbrueckii ssp. lactis ATCC 4797 in MRS soft agar and incubated at $37{ }^{\circ} \mathrm{C}$ for overnight. The shapes of clear inhibitory zones around the disks loaded with jenseniin $P$ were examined, to evaluate if the diffusion of the enzymes in the neighboring disk have partially deactivated the bacteriocin activity.

Thermal stability

Partially purified Jenseniin P $(5,120 \mathrm{AU} / \mathrm{ml})$ was held in boiling water in Eppendorf tubes for 90 min. Samples $(100 \mu \mathrm{l})$ were removed and placed on ice every $10 \mathrm{~min}$. The activity of each sample was measured using the microtiter plate method and was examined on Tris-Tricine SDSPAGE (18\% acrylamide).

pH stability

$\mathrm{HCl}$ and $\mathrm{NaOH}$ were added into sterile distilled water to prepare the standard solution at different $\mathrm{pHs}(1,2,7,12$, and 13). Partially purified jenseniin $\mathrm{P}(20 \mu \mathrm{l}$ at $5,120 \mathrm{AU} /$ $\mathrm{ml}$ ) were mixed with $300 \mu \mathrm{l}$ of each standard solution. The mixtures were then incubated at room temperature for $1 \mathrm{~h}$, neutralized with PBS buffer, and the remaining activity was quantified using the microtiter plate method as described above. Three experiments in triplicates were performed.

\section{New BLIS against $P$. acnes ATCC 6919}

The inhibitory activity of each eluate $(10,20,30,40,50$, and $100 \%$ acetonitrile solution) from $\mathrm{C} 18$ silica gel was separately tested against $L$. delbrueckii ssp. lactis ATCC 4797 and P. acnes ATCC 6919. In brief, to test the bacteriocin activity against $L$. delbrueckii ssp. lactis ATCC 4797, $10 \mu 1$ drops of each fraction were first spotted in duplicate on the top of MRS plate and allowed to dry in room temperature. $20 \mu \mathrm{l}$ of overnight culture was mixed with $5 \mathrm{ml}$ soft MRS agar and overlaid on top of the MRS plate and the plates were incubated at $37{ }^{\circ} \mathrm{C}$ overnight. To test bacteriocin activity against $P$. acnes ATCC 6919, $10 \mu \mathrm{l}$ drops of each fraction was spotted onto the top of NLA plate in duplicate and allowed to dry in room temperature. $5 \mathrm{ml}$ soft NLA agar inoculated with $50 \mu l 5$ days fresh culture was overlaid on top of NLA plates, and the plate was incubated at $37{ }^{\circ} \mathrm{C}$ anaerobically for 5 days. Clear inhibitory zones were examined after incubation.

Bacteriocin activity assay

The antimicrobial activity of the bacteriocin in liquid was quantified in a microtiter plate assay with slight modifications [2]. In brief, each well of the microtiter plate was filled with $50 \mu 1$ of serially diluted sample (twofold 
dilution) and $150 \mu \mathrm{l}$ of diluted overnight culture of $\mathrm{L}$. delbrueckii ssp. lactis ATCC 4797 in MRS broth (1\% final inoculation). The plates were incubated at $37^{\circ} \mathrm{C}$ for $12 \mathrm{~h}$, and the absorbance at $620 \mathrm{~nm}$ was measured with a microtiter plate reader. By definition, one unit of antimicrobial activity (AU) causes $50 \%$ growth inhibition $(50 \%$ of the turbidity of a control culture). The total antimicrobial unit was defined as the reciprocal of the highest dilution showing $50 \%$ inhibition of the indicator strain and was expressed in activity unit $(\mathrm{AU} / \mathrm{ml})$.

\section{Total protein BCA assay}

Total protein was measured by Thermo Scientific Micro BCA $^{\mathrm{TM}}$ Protein Assay Kit (Mfr. No. 23252) according to the standard protocol with slight modifications. The absorbance was measured at $570 \mathrm{~nm}$.

\section{Results and discussions}

\section{Production of jenseniin P in fed-batch fermentation}

Several batches of fermentation were conducted in jenseniin $\mathrm{P}$ production. Preliminary studies monitoring jenseniin $\mathrm{P}$ production for 33 days showed that bioactivity could be detected in the middle exponential phase (day 7), reached highest activity, kept stable in the early stationary phase (day 12-18), and drastically decreased from the middle to late stationary phases (day 19-31). The $\mathrm{OD}_{600}$ increased to 6 till day 17 and kept stable from day 18 to day 33 . The $\mathrm{pH}$ was relatively stable between 6 and 7 (data not shown).

In order to harvest the maximum amount of jenseniin $\mathrm{P}$ in the current batch, the supernatant was collected on day 18 . In the first 18 days, the trend of bacteriocin activity, turbidity $\left(\mathrm{OD}_{600}\right)$, and $\mathrm{pH}$ (15 days) were generally consistent with the previous 33-day studies. Viable cell numbers reached $10^{7} \mathrm{CFU} / \mathrm{ml}$ and kept consistent through day 5 to day 18 , while the turbidity $\left(\mathrm{OD}_{600}\right)$ increased to 6 until day 14 and remained stable through day 18 (Fig. 1). The increase in turbidity from day 6 to day 14 was not caused by viable cells increase, and it might be caused by cell morphology changes [19] or production of polysaccharide, which is similar with the fed-batch fermentation of $P$. thoenii P126 in producing jenseniin $G$ [20]. Based on the report that the initial high concentration of sodium lactate was shown to be toxic to $P$. jensenii, sodium lactate syrup was fed into the media daily to provide a sufficient carbon source [18].

The highest antimicrobial activity was obtained at early stationary phase, which is consistent with bacteriocin production by other propionibacteria: propionicin T1 [3], propionicin SM1 [10], and propionicin F [1]. This indicates that the production of jenseniin $\mathrm{P}$ is controlled by an inducible

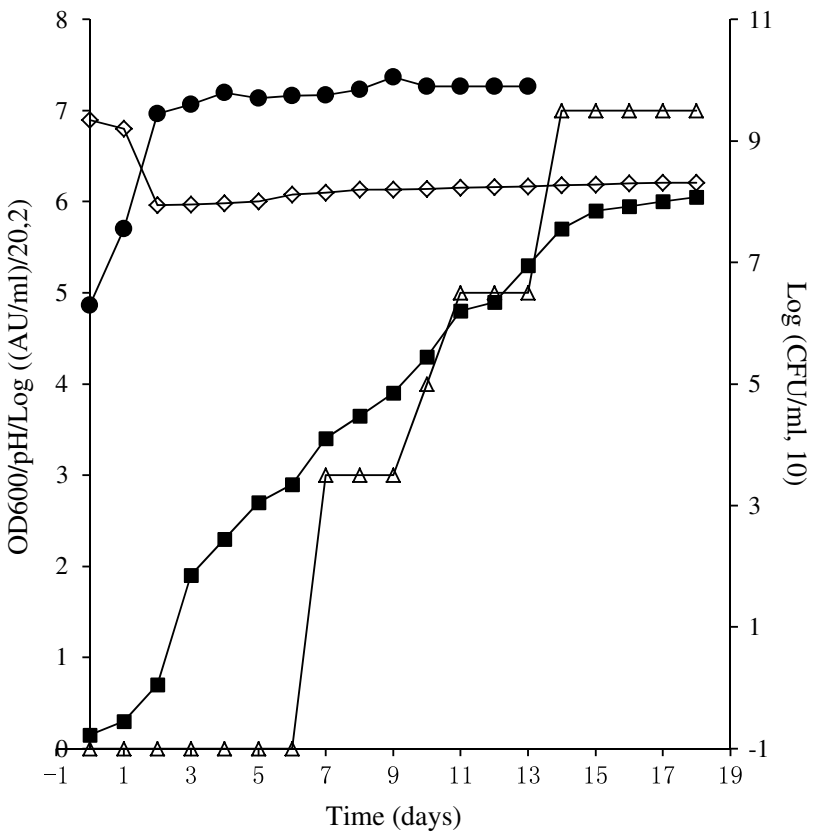

Fig. 1 P. jensenii B1264 growth and jenseniin P fermentation. Cultures were grown at $30{ }^{\circ} \mathrm{C}$ for 18 days with constant slow agitation anaerobically. $60 \%$ sodium lactate syrup was added to the fermenter twice daily to provide a constant $0.3 \%$ feeding by volume. Bacteriocin activity, turbidity $\left(\mathrm{OD}_{600}\right)$, viable cells count $(\mathrm{CFU} / \mathrm{ml})$, and $\mathrm{pH}$ were analyzed daily as indicated in materials and method. Filled square OD600; Open diamond $\mathrm{pH}$; Open triangle bacteriocin activity; $\log [(\mathrm{AU} / \mathrm{ml}) / 20,2] ;$ Filled circle $\log (\mathrm{CFU} / \mathrm{ml}, 10)$

promoter and the production of this bacteriocin might be initiated by environmental stress as a secondary metabolite, such as high cell density or nutrient depletion [21].

Jenseniin $\mathrm{P}$ has been previously produced using the same NLB medium either by batch or fed-batch fermentation by Prince [16], Graves [19], Ratnam [8], and Wallin [18]. The activity of jenseniin $\mathrm{P}$ produced by the fed-batch method was generally higher than in batch fermentations. However, the highest activity obtained in previous experiments was $400 \mathrm{AU} / \mathrm{ml}$ by Wallin using the spot-on-lawn assay method at a single day 14 [22]. To compare the results obtained in our current study, bacteriocin activity of our daily samples were also quantified using the same spot-on-lawn method for consistence. The result showed that the maximum bacteriocin activity obtained in our study was $1600 \mathrm{AU} / \mathrm{ml}$ which lasted for 5 days (days 14-18).

The increased production of jenseniin $\mathrm{P}$ in this study could be due to the use of a 4-day inoculum culture instead of the previously used 2-day culture, since the 4-day culture has a higher cell density and possibly better quorum sensing between cells. It is also possible that the harvest time in this study was accurately controlled based on timecourse studies, since the accumulation of jenseniin $P$ in the supernatant decreases after the maximum level is attained. 
Table 1 Partial purification summary of jenseniin P

\begin{tabular}{lcccc}
\hline & Bioactivity $(\mathrm{AU} / \mathrm{ml})$ & Total protein $(\mathrm{mg} / \mathrm{ml})$ & Specific activity (AU/mg) & Purification factor (fold) \\
\hline Supernatant of day 18 & $2,560 \pm 0$ & $6.6 \pm 0.8$ & $387 \pm 42$ & 1.0 \\
Dialyzed supernatant & $37,540 \pm 8,360$ & $12 \pm 2.3$ & $2,919 \pm 1042^{\mathrm{a}}$ & 7.5 \\
$50 \%$ elution fraction & $5,120 \pm 0$ & $0.7 \pm 0.1$ & $7,445 \pm 498^{\mathrm{a}}$ & 19.2 \\
\hline
\end{tabular}

${ }^{a}$ The specific acitivity of dialyzed supernatant and $50 \%$ elution fraction is significantly higher than the specific activity of supernatant of day 18 $(p<0.05), n=6$

\section{Partial purification of jenseniin $P$}

Jenseniin $\mathrm{P}$ was mainly purified by $\mathrm{C} 18$ resin silica gel column from 18 days supernatant after removing the cells and concentration by lyophilization. After C18 purification, bacteriocin activity of each individual fraction was measured against L. delbrueckii ssp. lactis ATCC 4797 and jenseniin $P$ activity was mainly in the $50 \%$ acetonitrile elution fraction and very low in $40 \%$ fraction. The bioactivity

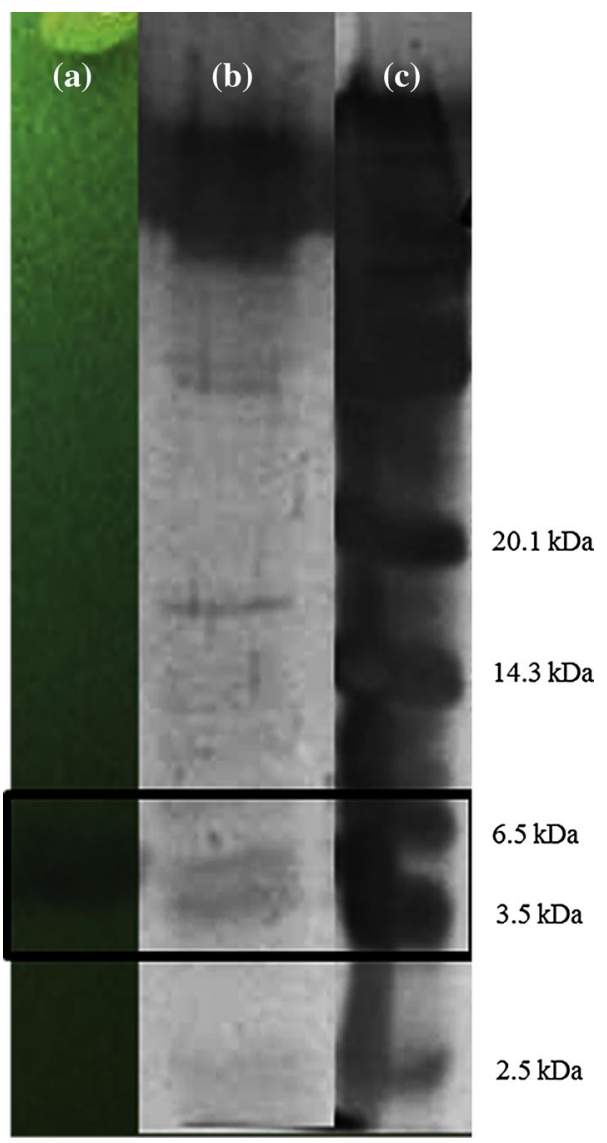

Fig. 2 SDS-PAGE and overlay assay of partially purified jenseniin $\mathrm{P}(5,120 \mathrm{AU} / \mathrm{ml})$. a $18 \%$ polyacrylamide gel after renaturation step with Triton X-100, on a MRS agar plate, overlaid with MRS soft agar (0.75\%) inoculated with L. delbrueckii ssp. lactis ATCC 4797; b Silver-stained protein gel; c Silver-stained low-range rainbow molecular weight marker after each purification step is shown (Table 1). Dialysis removed peptides smaller than $3.5 \mathrm{kDa}$ and purified 7.81fold. After purifying with $\mathrm{C} 18$, the $50 \%$ acetonitrile elution fraction had higher than $90 \%$ of the total activity against $L$. delbrueckii ssp. lactis ATCC 4797 and the specific activity increased 19.22-fold in the $50 \%$ acetonitrile elution fraction after $\mathrm{C} 18$ resin silica column.

In our preliminary studies, ammonium sulfate protein precipitation was also attempted to separate and concentrate jenseniin P. The activity was not precipitated out by lower than $60 \%$ ammonium sulfate, but due to high loss of total activity, ammonium sulfate precipitation was not adapted in this purification process. However, the result of ammonium sulfate precipitation indicated that jenseniin $\mathrm{P}$ is more polar than propionicin $\mathrm{T} 1$ and propionicin $\mathrm{F}$, since those two were mainly precipitated by $40 \%$ ammonium sulfate $[1,3]$.

Molecular weight determination

Two prominent bands with molecular weight ranging from 3.5 to $6.5 \mathrm{kDa}$ were observed on Tris-Tricine SDS-PAGE

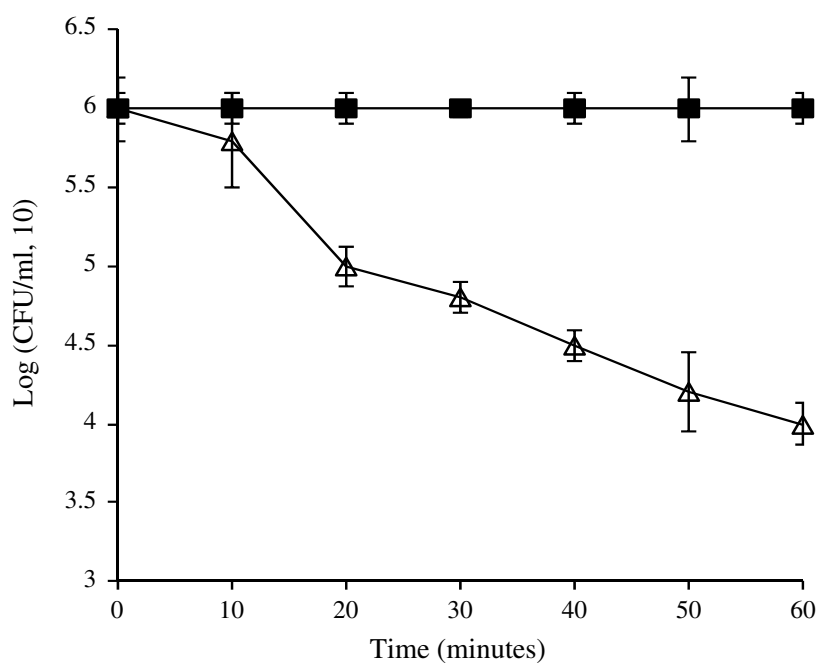

Fig. 3 Bactericial acitivity of partially purified jenseniin $P$ $(5,120 \mathrm{AU} / \mathrm{ml})$ against $L$. delbrueckii ssp. lactis ATCC 4797. CFU/ $\mathrm{ml}$ was determined by three independent experiments in triplicates. Mean and standard deviation were presented in the figure. Open triangle jenseniin $\mathrm{P}(5,120 \mathrm{AU} / \mathrm{ml})$; Filled square buffer control 
Fig. 4 Effect of enzyme treatment on further purified jenseniin $\mathrm{P}(5,120 \mathrm{AU} / \mathrm{ml})$ Left disks: a trypsin; b protease $\mathrm{K}$; c pronase; $\mathbf{d}$ catalase; e lysozyme. f MRS broth. Right disks: partial purified jenseniin $\mathrm{P}(5,120 \mathrm{AU} / \mathrm{ml})$ (a)

(b)

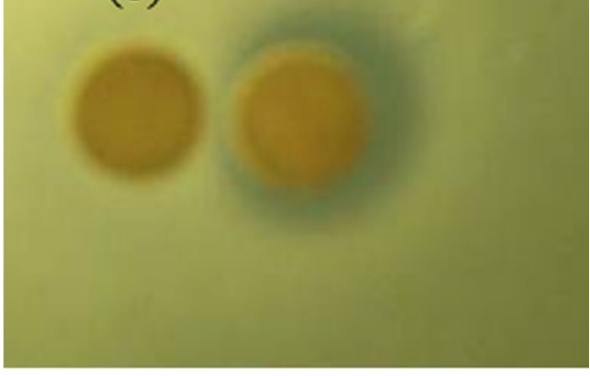

(c)

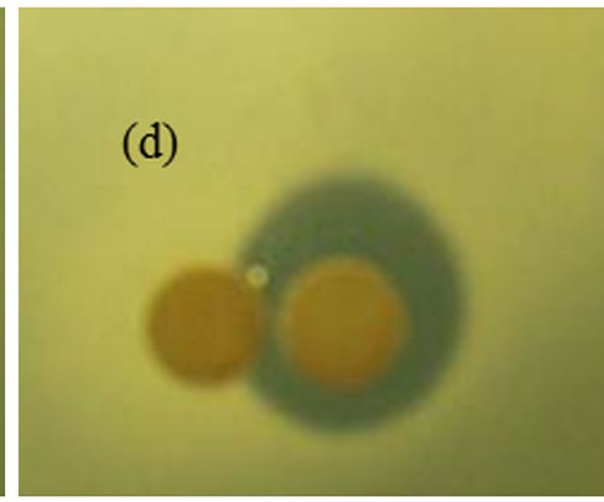

(e)

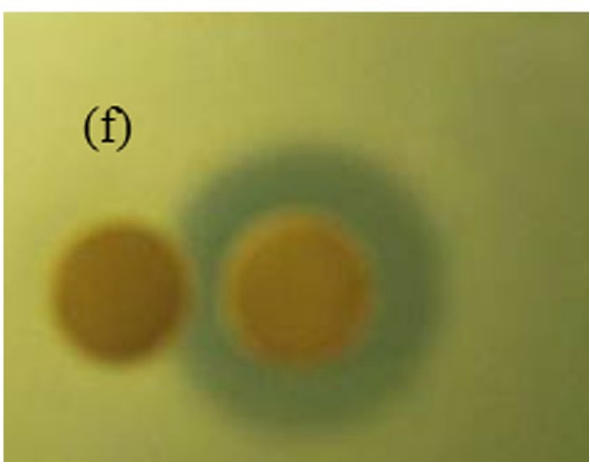

using the C-18 resin silica gel partially purified jenseniin $\mathrm{P}$ sample. A clear zone was formed on the duplicate gel in the corresponding position. The two bands were cut separately according to the location of the marker, and each band was washed with Triton X-100 and water and overlaid with the indicator strain. The lower band was determined to inhibit the growth of the indicator culture (data not shown). The molecular weight of jenseniin $\mathrm{P}$ was narrowed down to 4.5-5 $\mathrm{kDa}$ based on comparing the center of the inhibition zone and the lower band with the markers (Fig. 2).

\section{Mode of action of jenseniin $P$}

Treatment of L. delbrueckii ssp. lactis ATCC 4797 with jenseniin $P$ caused a $2.38 \log$ reduction in the population in $60 \mathrm{~min}$. This result indicated that jenseniin $\mathrm{P}$ has a bactericidal mode of action instead of bacteriostatic (Fig. 3). Most bacteriocins produced by LAB have a bactericidal mode of action [23].
The fast acting mode of action indicated that jenseniin P might act on the membrane level against indicator strains.

\section{Enzyme treatment}

In this present work, activity of jenseniin $\mathrm{P}$ was inactivated by trypsin, proteinase $\mathrm{K}$, and pronase $\mathrm{E}$, as indicated by altered clear zones around the disk. Activity of jenseniin $P$ was not affected by lysozyme and catalase (Fig. 4). Jenseniin $\mathrm{P}$ showed proteinaceous nature by being inactivated by the non-specific enzymes proteinase $\mathrm{K}$ and pronase. It indicated that jenseniin $\mathrm{P}$ contains lysine or arginine residues, since it was also inactivated by trypsin [24].

\section{Heat stability}

Jenseniin $\mathrm{P}$ was partially inactivated by boiling water treatment for $90 \mathrm{~min}$, showing a $2-\log$ reduction in activity 


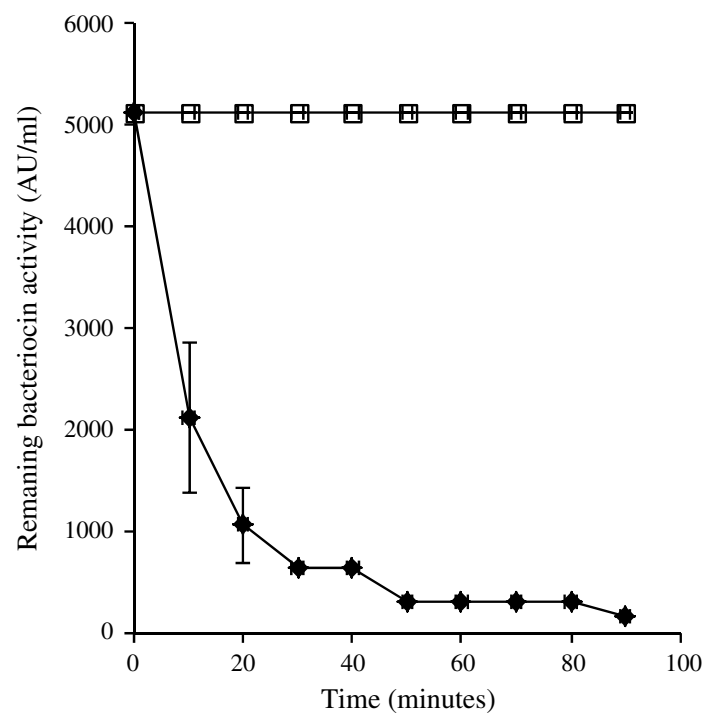

Fig. 5 Heat treatment of partially purified jenseniin $\mathrm{P}(5,120 \mathrm{AU} / \mathrm{ml})$. Activity against $L$. delbrueckii ssp. lactis ATCC 4797 was determined by three independent experiments in triplicates. Open square $4{ }^{\circ} \mathrm{C}$, control; Filled diamonds $100{ }^{\circ} \mathrm{C}$

(Fig. 5). High temperatures were reported to affect the activity of some bacteriocins: propionicin PLG-1 loses activity [25] while jenseniin $G$ remains stable [7]. As indicated by SDS-PAGE, the jenseniin P band was more dominant compared to other contaminant proteins after heat treatment (data not shown).
pH stability

After the samples were mixed with different $\mathrm{pH}$ standards ranging from 2 to 13 , the $\mathrm{pH}$ of different mixtures changed slightly, from 1.9 to 12.8 . Under different acidic or basic conditions, jenseniin $\mathrm{P}$ exhibited the same activity $(320 \mathrm{AU} / \mathrm{ml})$ after being treated for $1 \mathrm{~h}$, which indicated that the activity of jenseniin $P$ was not affected by moderate to extreme acidic or basic conditions. The stability of jenseniin $\mathrm{P}$ under extreme $\mathrm{pH}$ conditions indicated its potential as a food preservative or starter culture. Some bacteriocins are $\mathrm{pH}$-dependent since their net charge was affected in different $\mathrm{pH}$ environments. For example, some lantibiotic and non-lanthionine-containing bacteriocins show higher activity at lower $\mathrm{pH}$ (pH 5 and below) than at physiological $\mathrm{pH}$, because their adsorption to the cell surface of Gram-positive bacteria, including the producing cells is $\mathrm{pH}$-dependent [22].

Discovery of a new bacteriocin-like substance

The $30 \%$ acetonitrile elution fraction inhibited the growth of $P$. acnes ATCC 6919, but did not inhibit the growth of $L$. delbrueckii ssp. lactis ATCC 4797. The $50 \%$ acetonitrile elution fraction inhibited the growth of $L$. delbrueckii ssp. lactis ATCC 4797, but did not inhibit the growth of P. acnes ATCC 6919 (Fig. 6). $40 \%$ fraction only slightly inhibits the L. delbrueckii ssp. lactis ATCC 4797 (data not shown).
Fig. 6 Spot-on-lawn assay of $50 \%$ acetonitrile eluent and $30 \%$ acetonitrile eluent. a $50 \%$ acetonitrile eluent on L. delbrueckii; b $30 \%$ acetonitrile eluent on L. delbrueckii ssp. lactis ATCC 4797; c $50 \%$ acetonitrile eluent on $P$. acnes 6919; d $30 \%$ acetonitrile eluent on P. acnes 6919
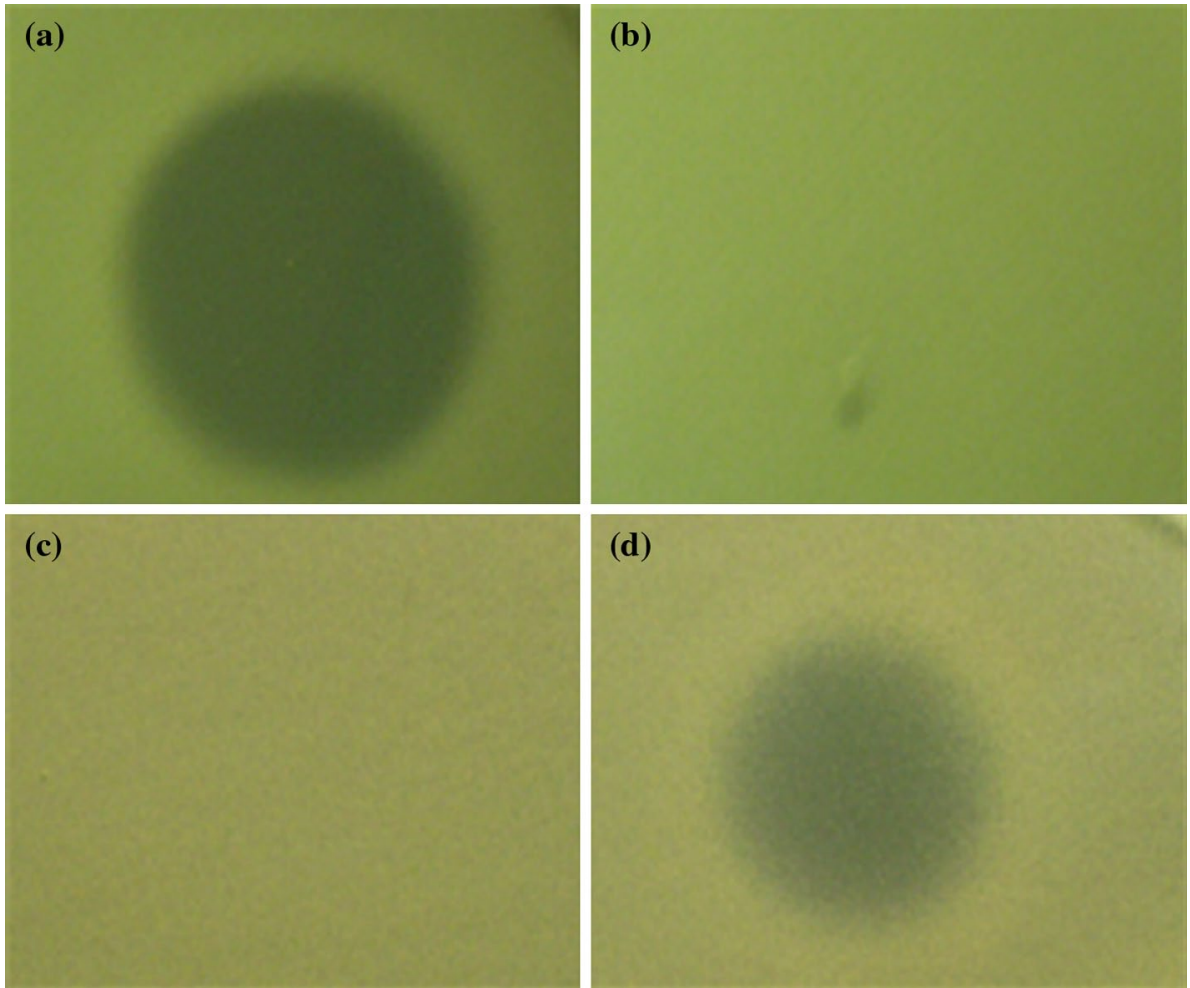
10,20 , and $100 \%$ acetonitrile elution fractions inhibited none of the indicator strains. It is highly possible that the inhibitory agent in the $30 \%$ fraction is a new BLIS based on the fact that this BLIS was neither removed by dialysis with a cutoff of $3.5 \mathrm{kDa}$, nor eluted by up to $20 \%$ acetonitrile wash on $\mathrm{C} 18$ silicon resin. However, the proteinaceous nature needs to be further determined by enzyme digestion assays. In fact, since the purity of both 30 and $50 \%$ acetonitrile elution fractions were not confirmed, more than one BLIS are possible to exist in each fraction. This BLIS against $P$. acne has the potential to be an alternative acne vulgaris treatment since antibiotic resistance is an emerging problem in acne treatment [12].

\section{Conclusion}

This research improved the fed-batch fermentation method to produce jenseniin $\mathrm{P}$ in a new cultivation system. The partially purified jenseniin $\mathrm{P}$ was determined to be heat labile and $\mathrm{pH}$ stable. Results in this work also indicated that more than one bacteriocin or BLIS might be produced by $P$. jensenii $\mathrm{B} 1264$. Further purification and analyses are needed in the future to accurately evaluate their potential in both food and pharmaceutical industries.

Acknowledgments We would like to acknowledge Dr. Mike Henson for providing the bioreactor for our experiments. We acknowledge Dr. Susan Barefoot in technical advice and reviewing the manuscript.

\section{Conflict of interest None.}

Compliance with Ethics Requirements This article does not contain any studies with human or animal subjects.

\section{References}

1. Brede DA, Faye T, Johnsborg O, Odegard I, Nes IF, Holo H (2004) Molecular and genetic characterization of propionicin F, a bacteriocin from Propionibacterium freudenreichii. Appl Environ Microbiol 70(12):7303-7310

2. Faye T, Brede DA, Langsrud T, Nes IF, Holo H (2002) An antimicrobial peptide is produced by extracellular processing of a protein from Propionibacterium jensenii. J Bacteriol 184(13):3649-3656

3. Faye T, Langsrud T, Nes IF, Holo H (2000) Biochemical and genetic characterization of propionicin $\mathrm{T} 1$, a new bacteriocin from Propionibacterium thoenii. Appl Environ Microbiol 66(10):4230-4236

4. Zarate G, Gonzalez S, Chaia AP (2004) Assessing survival of dairy propionibacteria in gastrointestinal conditions and adherence to intestinal epithelia. Methods Mol Biol 268:423-432

5. Vorobjeva LI (1999) Propionibacteria. Kluwer Academic Publishers, Dordrecht

6. Danilova IV, Lee HAO, Tourova TP, Ryzhkova EP, Netrusov AI (2012) Propionibacterium freudenreichii strains as antibacterial agents at neutral $\mathrm{pH}$ and their production on food grade media fermented by some lactobacilli. J Food Saf 32(1):48-58

7. Grinstead DA, Barefoot SF (1992) Jenseniin G, a heat-stable bacteriocin produced by Propionibacterium jensenii P126. Appl Environ Microbiol 58(1):215-220

8. Ratnam P, Barefoot SF, Prince LD, Bodine AB, McCaskill LH (1999) Partial purification and characterization of the bacteriocin produced by Propionibacterium jensenii B1264. Lait 79:125-136

9. Lyon WJ, Glatz BA (1993) Isolation and purification of propionicin PLG-1, a bacteriocin produced by a strain of Propionibacterium thoenii. Appl Environ Microbiol 59(1):83-88

10. Miescher S, Stierli MP, Teuber M, Meile L (2000) Propionicin SM1, a bacteriocin from Propionibacterium jensenii DF1: isolation and characterization of the protein and its gene. Syst Appl Microbiol 23(2):174-184

11. McGinley KJ, Webster GF, Leyden JJ (1978) Regional variations of cutaneous propionibacteria. Appl Environ Microbiol 35(1):62-66

12. Yates V (2005) Acne: current treatment. Clin Med 5(6):569-572

13. Lee YJ, Choi HJ, Kang TW, Kim HO, Chung MJ, Park YM (2008) CBT-SL5, a bacteriocin from Enterococcus faecalis, suppresses the expression of interleukin- 8 induced by Propionibacterium acnes in cultured human keratinocytes. J Microbiol Biotechnol 18(7):1308-1316

14. Bowe WP, Filip JC, DiRienzo JM, Volgina A, Margolis DJ (2006) Inhibition of propionibacterium acnes by bacteriocin-like inhibitory substances (BLIS) produced by Streptococcus salivarius. J Drugs Dermatol 5(9):868-870

15. Nishie M, Nagao J-I, Sonomoto K (2012) Antibacterial peptides "bacteriocins": an overview of their diverse characteristics and applications. Biocontrol Sci 17(1):1-16

16. Prince L (1993) Detection and partial characterization of a bacteriocin, jenseniin P, from Propionibacterium jensenii P1264. Master's Thesis, Clemson University, South Carolina, USA

17. Ratnam P (1997) Partial purification and characterization of the anti-acne bacteriocin Jenseniin P. Doctoral dissertation. Doctoral dissertation, Clemson University, South Carolina, USA

18. Wallin JC (2000) Increased production of the bacteriocin Jenseniin P in fed batch cultures of Propionibacterium jensenii B1264. Master's Thesis, Clemson University, South Carolina, USA

19. Graves DM (1998) Growth characteristics of a Propionibacteria that produces jenseniin P. Master's Thesis, Clemson University, South Carolina, USA

20. Ekinci FY, Barefoot SF (2006) Fed-batch enhancement of jenseniin G, a bacteriocin produced by Propionibacterium thoenii (jensenii) P126. Food Microbiol 23(4):325-330

21. Riley MA, Gordon DM (1999) The ecological role of bacteriocins in bacterial competition. Trends Microbiol 7(3):129-133

22. Fujita K, Ichimasa S, Zendo T, Koga S, Yoneyama F, Nakayama J, Sonomoto K (2007) Structural analysis and characterization of lacticin Q, a novel bacteriocin belonging to a new family of unmodified bacteriocins of gram-positive bacteria. Appl Environ Microbiol 73(9):2871-2877

23. Ennahar S, Sashihara T, Sonomoto K, Ishizaki A (2000) Class IIa bacteriocins: biosynthesis, structure and activity. FEMS Microbiol Rev 24(1):85-106

24. Olsen JV, Ong SE, Mann M (2004) Trypsin cleaves exclusively $\mathrm{C}$-terminal to arginine and lysine residues. Mol Cell Proteomics 3(6):608-614

25. Lyon WJ, Glatz BA (1991) Partial purification and characterization of a bacteriocin produced by Propionibacterium thoenii. Appl Environ Microbiol 57(3):701-706 